Bangladesh J. Zool. 40(1):147-153, 2012

\title{
BIOACCUMULATION OF SOME HEAVY METALS IN AYRE FISH (SPERATA AOR HAMILTON, 1822), SEDIMENT AND WATER OF DHALESHWARI RIVER IN DRY SEASON
}

\author{
Abu Tweb Abu Ahmed*, Suman Mandal, Didarul Alam Chowdhury ${ }^{1}$, \\ Abu Rayhan M. Tareq ${ }^{1}$ and M. Mizanur Rahman \\ Department of Zoology, University of Dhaka, Dhaka-1000, Bangladesh
}

\begin{abstract}
The present study was carried out to determine the level of bioaccumulation of some heavy metals in a freshwater fish Ayre (Sperata aor Hamilton, 1822) collected from Rajfulbaria $\left(23^{\circ} 48^{\prime} 56.36^{\prime \prime} \mathrm{N}\right.$ and $\left.90^{\circ} 14^{\prime} 54.04^{\prime \prime} \mathrm{E}\right)$ of Dhaleshwari river. Four heavy metals, namely chromium $(\mathrm{Cr})$, copper $(\mathrm{Cu})$, lead $(\mathrm{Pb})$, and cadmium $(\mathrm{Cd})$ were selected for this study. Metal concentrations were determined by Flame Atomic Absorption Spectrophotometer after nitric acid digestion of samples. The concentrations of accumulated heavy metals in fish were also compared with the concentrations of metals in the sediments and waters of that river. The level of bioaccumulations in different organs of $S$. aor were determined separately and compared among them. Average bioaccumulation levels in S. aor were $\mathrm{Cr}: 1.458 \mathrm{mg} / \mathrm{kg}, \mathrm{Cu}: 31.500 \mathrm{mg} / \mathrm{kg}, \mathrm{Pb}: 18.776 \mathrm{mg} / \mathrm{kg}$ and $\mathrm{Cd}$ : $0.487 \mathrm{mg} / \mathrm{kg}$ of dry weight. The levels of heavy metals in sediments were $\mathrm{Cr}$ : $27.393 \mathrm{mg} / \mathrm{kg}$, Cu: $37.450 \mathrm{mg} / \mathrm{kg}, \mathrm{Pb}: 15.797 \mathrm{mg} / \mathrm{kg}$ and $\mathrm{Cd}: 2.083 \mathrm{mg} / \mathrm{kg}$, and in water were $\mathrm{Cr}: 0.130 \mathrm{ppm}, \mathrm{Cu}: 0.000 \mathrm{ppm}, \mathrm{Pb}: 0.201 \mathrm{ppm}$ and $\mathrm{Cd}: 0.001 \mathrm{ppm}$. The bioaccumulation of these four heavy metals in fish organs, sediment and water samples were also compared with FAO approved standard levels and other related studies, and found that the levels of bioaccumulation in the Dhaleshwari river exceeded all the standard levels.
\end{abstract}

Key words: Bioaccumulation, heavy metals, FAAS, Ayre fish.

\section{INTRODUCTION}

Heavy metals have relatively high atomic weight and toxic at low concentration. They do not degrade or are not destroyed; they generally do not breakdown into less harmful constituents. They accumulate where they are released. As trace elements, some heavy metals (e.g. copper, selenium, zinc etc.) are essential to maintain the metabolism of human body. However, at higher concentrations they can lead to poisoning (Bendico and Lavilla 2003). Some heavy metals like mercury, cadmium and lead are highly toxic in nature. The toxic actions of trace elements or heavy metals occur due to bioaccumulation and biomagnifications of the elements in the tissues of living organisms. With the increased urbanization and industrialization, there has been a rapid increase in the municipal waste water (sewage water and industrial effluents)

*Corresponding author: E-mail: abu_tweb@yahoo.com; ${ }^{1}$ Atomic Energy Research Establishment, Savar, Dhaka, Bangladesh. 
which in turn has intensified the environmental pollution (Boyle et al. 2004). Some of the heavy metals (e.g. mercury, cadmium, arsenic, lead and chromium) are dangerous to health or to the environment, some (e.g. zinc and lead) may cause corrosion, some are harmful in other ways (e.g. arsenic may pollute catalysts). Within the European community the 13 elements of highest concern are arsenic, cadmium, cobalt, chromium, copper, mercury, manganese, nickel, lead, tin, and thallium, the emissions of which are regulated in waste incinerators. Some of these elements (cobalt, copper, chromium, manganese and nickel) are actually necessary for humans in minute amounts while others are carcinogenic or toxic, affecting, among others, the central nervous system (by manganese, mercury, lead and arsenic), the kidneys or liver (by mercury, lead, cadmium and copper) or skin, bones, or teeth (by nickel, cadmium, copper and chromium) (Bhattacharya et al. 2007). The problem-causing property of heavy metals is their non-degradability. Once they enter the environment they remain there for long time. The metals tend to accumulate in soil and sediment, with immobilization due to geological procedure and therefore extremely slow processes. Accumulation in the food chain may lead to an increased stock in biota, thereby magnifying the human dose.

Pollution of rivers causes the degradation of biodiversity. Heavy metals contamination creates problem in those species, specially the fishes which survive in polluted rivers and this problem is directed toward the health damage of human, the consumers of fishes. The study area, Dhaleshwari River, is one of the main local sources of food fishes for Dhaka city. The river is polluted by various industries near Savar, Dhamrai, and eastern Manikgonj. The objective of the present study was to determine the concentration level of some important heavy metals in fishes, sediment and water in order to know the level of pollution in Dhaleshwari river.

\section{MATERIAL AND METHODS}

Samples of Ayre fish, Long Whischard Catfish (Sperata aor Hamilton, 1822), sediment and water were collected from Dhaleshwari river at Rajfulbaria (Fig. 1) in Savar, Dhaka $\left(23^{0} 48^{\prime} 56.36^{\prime \prime} \mathrm{N}\right.$ and 90 ${ }^{\circ} 14^{\prime} 54.04^{\prime \prime}$ E) during November 2010 January 2011. Fishes were caught by using a seine net. The samples were prepared step by step according to the recommended procedures by AOAC (AOAC 2002). The fishes were weighed by a spring balance in the field and an electric balance in laboratory according to weight range. After the dissection of the collected fishes (Fig. 2), all organs (namely flesh, kidney, gills, digestive tract and liver) were taken separately in a petridish and weighed by using an electric balance and then taken into polybags separately. The polybags were sealed and 
taken into an icebox. Sediment and water were collected manually by using scoop and plastic water sampling bottles. Fish organs, sediment and water were separately digested by nitric acid $\left(\mathrm{HNO}_{3}\right)$ and perchloric acid $\left(\mathrm{HClO}_{4}\right)$. The concentration of heavy metals (namely chromium, copper, lead and cadmium) were determined by Flame Atomic Absorption Spectrophotometer (FAAS, model: Perkin Elmar Analyst 800) in Atomic Energy Research Establishment Laboratory, Savar, Dhaka. Data were analyzed by Winlab $32^{\mathrm{TM}}$ and then by SPSS.

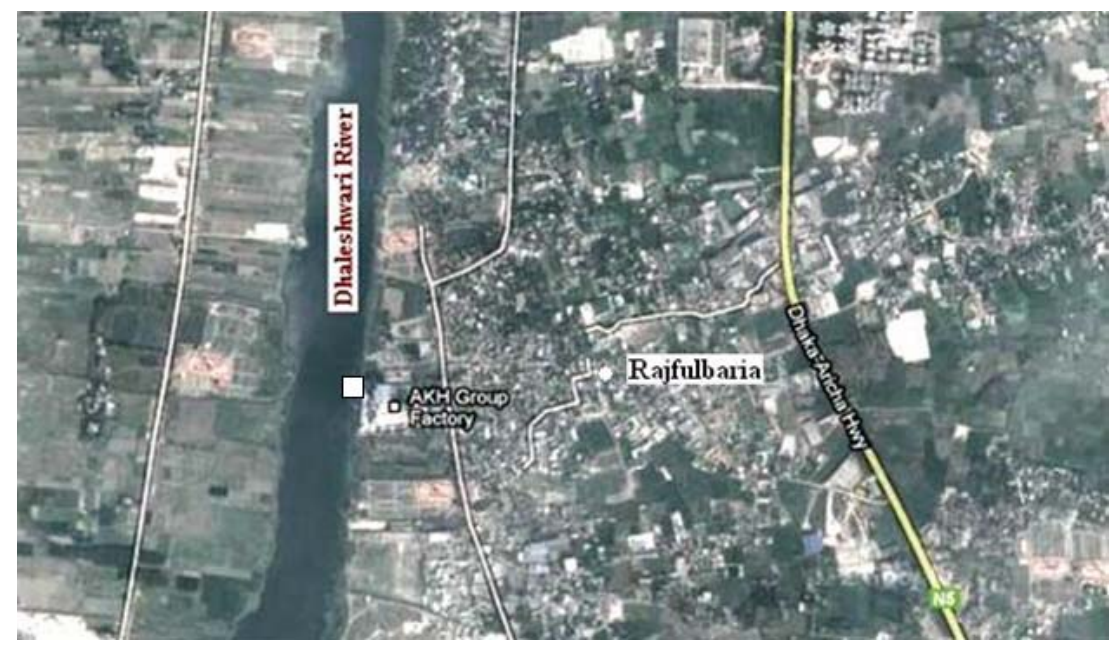

Fig. 1. Sampling site ( $\square$ ) in Dhaleshwari river

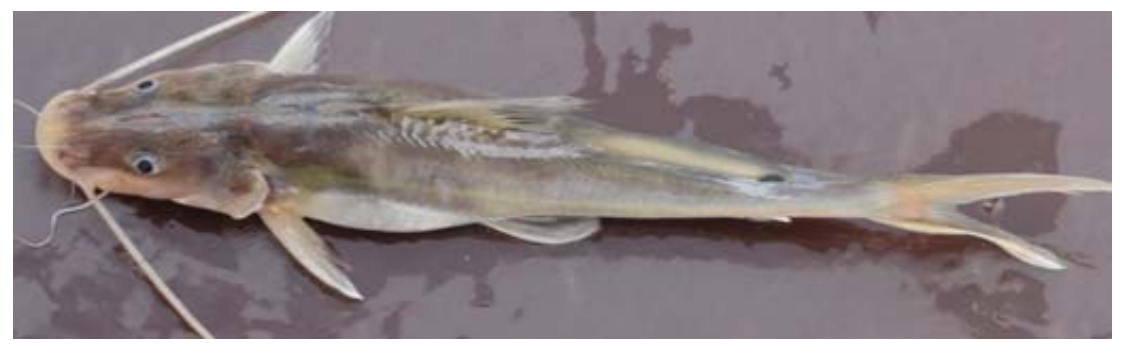

Fig. 2. Sample fish, Ayre (Sperata aor) in dorsal view

\section{RESULTS AND DISCUSSION}

In Sperata aor, the level of concentration of heavy metals was determined from five organs (namely flesh, kidney, gills, digestive tract and liver) separately and the order of toxicity in flesh as well as other organs was: $\mathrm{Cu}>\mathrm{Pb}>\mathrm{Cr}>\mathrm{Cd}$.

The bioaccumulation of chromium $(\mathrm{Cr})$ in the kidney and gills showed the highest level $(2.153$ and $2.15 \mathrm{mg} / \mathrm{kg})$ where the liver contained the lowest level 
(below the detection level). However, the average $\mathrm{Cr}$ concentration in $\mathrm{S}$. aor was $1.458 \mathrm{mg} / \mathrm{kg}$ which was lesser than that in the sediment $(27.39 \mathrm{mg} / \mathrm{kg})$. Flesh and digestive tract contained $1.37 \mathrm{mg} / \mathrm{kg}$ and $1.62 \mathrm{mg} / \mathrm{kg}$ of $\mathrm{Cr}$ (Table 1 and Fig. 3), and the standard acceptable level of $\mathrm{Cr}$ in fish is $7.0 \mathrm{mg} / \mathrm{kg}$ (FAO 2010). The water of Dhaleshwari river also contains a high level of $\mathrm{Cr}(0.1302 \mathrm{ppm})$ where maximum allowable concentration (MAC) in Bangladesh is $0.05 \mathrm{ppm}$, WHO standard is $0.05 \mathrm{ppm}$ and USEPA standard is $0.1 \mathrm{ppm}$ for drinking water. The standard level of $\mathrm{Cr}$ in fish is $7.0 \mathrm{mg} / \mathrm{kg}$ where the fish gills contained 2.16 $\mathrm{mg} / \mathrm{kg}$. The order of concentrations of $\mathrm{Cr}$ in various organs of fish sample was: kidney $>$ gills $>$ digestive tract $>$ flesh $>$ liver.

Table 1. Concentrations of chromium, copper, lead and cadmium in various organs of $\mathbf{S}$. aor and sediment and water of Dhaleshwari river (in $\mathrm{mg} / \mathrm{kg}$ or $\mathrm{ppm}$ )

\begin{tabular}{lccccc}
\hline Samples & $\mathrm{N}$ & $\begin{array}{c}\text { Chromium } \\
(\mathrm{M} \pm \mathrm{SD})\end{array}$ & $\begin{array}{c}\text { Copper } \\
(\mathrm{M} \pm \mathrm{SD})\end{array}$ & $\begin{array}{c}\text { Lead } \\
(\mathrm{M} \pm \mathrm{SD})\end{array}$ & $\begin{array}{c}\text { Cadmium } \\
(\mathrm{M} \pm \mathrm{SD})\end{array}$ \\
\hline Flesh & 10 & $1.370 \pm 0.370$ & $18.227 \pm 0.452$ & $15.077 \pm 8.764$ & $0.170 \pm 0.130$ \\
Kidney & 10 & $2.153 \pm 1.210$ & $93.063 \pm 0.655$ & $11.767 \pm 4.989$ & $0.413 \pm 0.049$ \\
Gills & 10 & $2.150 \pm 0.693$ & $15.830 \pm 0.548$ & $47.623 \pm 6.264$ & $0.307 \pm 0.023$ \\
Digestive Tract & 10 & $1.617 \pm 0.621$ & $16.117 \pm 1.656$ & $19.413 \pm 4.517$ & $1.457 \pm 0.158$ \\
Liver & 10 & $0.000 \pm 0.000$ & $14.297 \pm 0.514$ & $0.000 \pm 0.00$ & $0.089 \pm 0.011$ \\
Average & & $1.458 \pm 0.883$ & $31.500 \pm 1.287$ & $18.776 \pm 2.667$ & $0.487 \pm 0.055$ \\
Sediment & 3 & $27.393 \pm 1.292$ & $37.450 \pm 0.331$ & $15.797 \pm 1.252$ & $2.083 \pm 0.015$ \\
Water & 3 & $0.130 \pm 0.007$ & $0.000 \pm 0.000$ & $0.201 \pm 0.076$ & $0.001 \pm 0.000$ \\
\hline
\end{tabular}

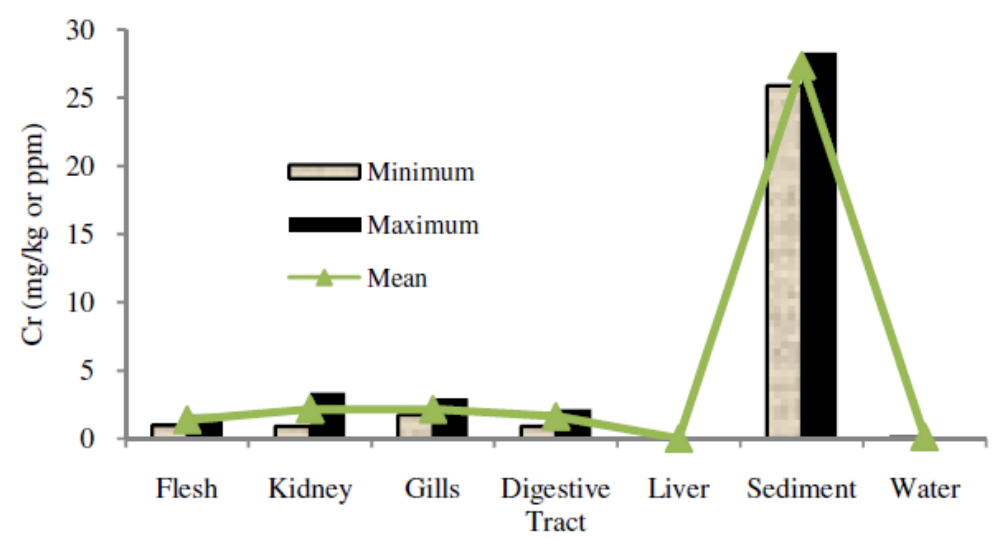

Fig. 3. Mean, minimum and maximum concentrations of Chromium in different organs of $S$. aor, sediment and water of Dhaleshwari river.

The concentration of $\mathrm{Cu}$ was the highest in kidney $(93.06 \mathrm{mg} / \mathrm{kg})$ and the lowest in liver $(14.29 \mathrm{mg} / \mathrm{kg})$ in $S$. aor. The overall concentrations of $\mathrm{Cu}$ in various organs were flesh: $18.23 \mathrm{mg} / \mathrm{kg}$, kidney: $93.06 \mathrm{mg} / \mathrm{kg}$, gills: 15.83 $\mathrm{mg} / \mathrm{kg}$, digestive tract: $16.12 \mathrm{mg} / \mathrm{kg}$ and liver: $14.29 \mathrm{mg} / \mathrm{kg}$, and the order of 
contamination was: kidney $>$ flesh $>$ digestive tract>gill $>$ liver. The average $\mathrm{Cu}$ concentration $(31.50 \mathrm{mg} / \mathrm{kg})$ of $S$. aor was lower than the $\mathrm{Cu}$ concentration in sediment $(37.45 \mathrm{mg} / \mathrm{kg})$. The levels of $\mathrm{Cu}$ in the fish was higher than the standard level (Cu: $30 \mathrm{mg} / \mathrm{kg}$ ) approved by FAO (FAO 2010). Cu concentration in the water of Dhaleshwari was below the detection level (BDL) of Flame Atomic Absorption Spectrophotometer (Table 1 and Fig. 4).

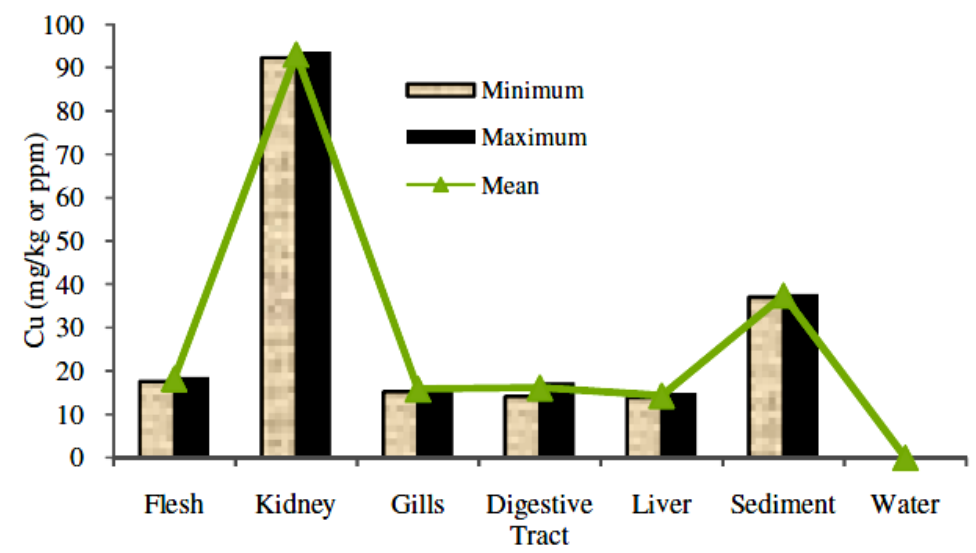

Fig. 4. Mean, minimum and maximum concentrations of copper in different organs of $S$. aor, sediment and water of Dhaleshwari river.

The flesh of $S$. aor contained $15.076 \mathrm{mg} / \mathrm{kg}$ of lead where FAO standard concentration is $2.0 \mathrm{mg} / \mathrm{kg}$ for fish. Lead concentration in the gills of $S$. aor showed the highest level of bioaccumulation $(47.62 \mathrm{mg} / \mathrm{kg})$, while the liver showed the least concentration (BDL). Sediment contained $15.8 \mathrm{mg} / \mathrm{kg}$ of $\mathrm{Pb}$. The water of Dhaleshwari river contains high concentration of $\mathrm{Pb}(0.2014 \mathrm{ppm})$ which exceeds standard levels (WHO 1993, USEPA 2000) and MAC in Bangladesh (GoB 1997). $\mathrm{Pb}$ contaminates the gills directly from water and for this reason the gills contain higher level of $\mathrm{Pb}$. Lead concentrations in fish sample were flesh: $15.07 \mathrm{mg} / \mathrm{kg}$, kidney: $11.76 \mathrm{mg} / \mathrm{kg}$, gills: $47.62 \mathrm{mg} / \mathrm{kg}$, and digestive tract: $19.41 \mathrm{mg} / \mathrm{kg}$ (Table 1 and Fig. 5). The order of contamination of $\mathrm{Pb}$ in $\mathrm{S}$. aor was gills $>$ digestive tract $>$ flesh $>$ kidney $>$ liver.

In $S$. aor, Cd bioaccumulation level was the highest in the digestive tract $(1.46 \mathrm{mg} / \mathrm{kg})$ and the lowest in the liver $(0.089 \mathrm{mg} / \mathrm{kg})$. The concentrations of cadmium in various organs were flesh: $0.17 \mathrm{mg} / \mathrm{kg}$, kidney: $0.413 \mathrm{mg} / \mathrm{kg}$, gills: $0.307 \mathrm{mg} / \mathrm{kg}$, digestive tract: $1.457 \mathrm{mg} / \mathrm{kg}$ and liver: $0.089 \mathrm{mg} / \mathrm{kg}$ (Table 1 and Fig. 6). The order of contamination was: digestive tract $>$ kidney $>$ gills $>$ flesh>liver. The edible portion of fish body (flesh) contained $0.17 \mathrm{mg} / \mathrm{kg}$ of cadmium where FAO approved level of cadmium concentration is $0.1 \mathrm{mg} / \mathrm{kg}$. 
The cadmium concentration in the sediment of Dhaleshwari river was greater than FAO standard as well as the average $(0.487 \mathrm{mg} / \mathrm{kg})$ bioaccumulation in fish ( $S$. aor). In the water, $\mathrm{Cd}$ concentration was $0.001 \mathrm{ppm}$ where maximum allowable concentration (MAC) in Bangladesh is $0.1 \mathrm{ppm}$, WHO standard is 0.01 ppm and USEPA standard is 0.015ppm (WHO 1993, USEPA 2000)

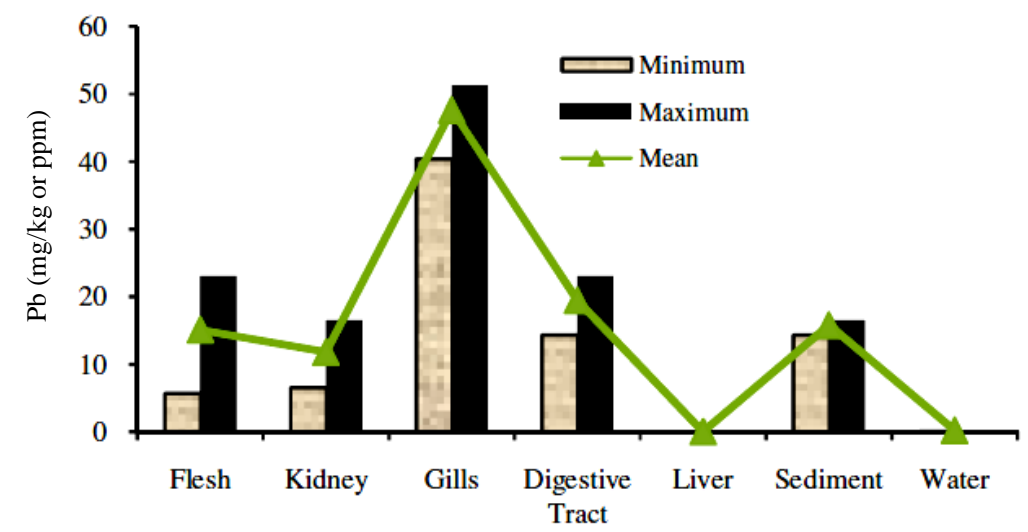

Fig. 5. Mean, minimum and maximum concentration of Lead in different organs of $S$. aor, sediment and water of Dhaleshwari river.

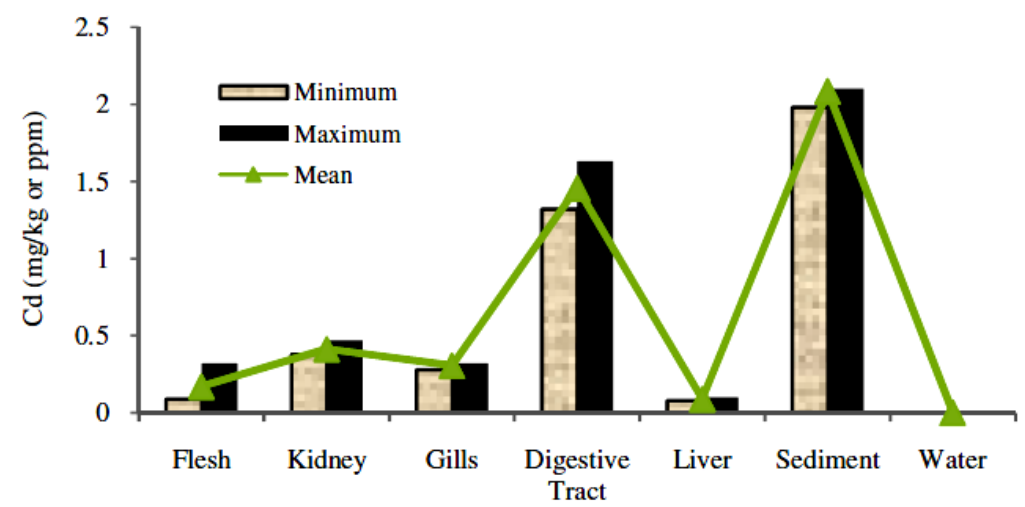

Fig. 6. Mean, minimum and maximum concentration of Cadmium in different organs of S. aor, sediment and water.

In some commercial fishes of the Gulf of Cambay, Sharma et al. (2009) found $\mathrm{Cu}: 43, \mathrm{Zn}: 55, \mathrm{Cd}: 4.05$ and $\mathrm{Pb}: 2.43 \mathrm{mg} / \mathrm{kg}$, and the order of toxicity was: $\mathrm{Zn}>\mathrm{Cu}>\mathrm{Cd}>\mathrm{Pb}$. In the present study, the level of heavy metals in the fish of Dhaleshwari was found as $\mathrm{Cu}: 31.476 \mathrm{mg} / \mathrm{kg}, \mathrm{Cd}: 0.482 \mathrm{mg} / \mathrm{kg}, \mathrm{Cr}: 1.322$ $\mathrm{mg} / \mathrm{kg}$ and $\mathrm{Pb}: 15.988 \mathrm{mg} / \mathrm{kg}$, and the order of toxicity was: $\mathrm{Cu}>\mathrm{Pb}>\mathrm{Cr}$.

Haque et al. (2003) determined the bioaccumulation of trace metals in $M$. vittatus collected from Buriganga river and found $\mathrm{Cu}$ : $3.595-5.139 \mathrm{mg} / \mathrm{kg}, \mathrm{Pb}$ : $1.031-3.3578 \mathrm{mg} / \mathrm{kg}, \mathrm{Cr}: 2.04-11.79 \mathrm{mg} / \mathrm{kg}$ and $\mathrm{Cd}: 0.109-1.102 \mathrm{mg} / \mathrm{kg}$ 
whereas, in this study, bioaccumulation in S. aor collected from Dhaleshwari were found $\mathrm{Cu}: 31.476 \mathrm{mg} / \mathrm{kg}, \mathrm{Pb}: 15.988 \mathrm{mg} / \mathrm{kg}, \mathrm{Cr}: 1.322 \mathrm{mg} / \mathrm{kg}$ and $\mathrm{Cd}$ : $0.482 \mathrm{mg} / \mathrm{kg}$, i.e. the levels of bioaccumulation in fish of Dhaleshwari river is lower than that of Buriganga river.

In the sediment, the toxicity order was $\mathrm{Cu}>\mathrm{Cr}>\mathrm{Pb}>\mathrm{Cd}$ in Dhaleshwari river. Water samples showed high levels of $\mathrm{Pb}$, but $\mathrm{Cu}$ and $\mathrm{Cd}$ were below the detection level. In the water sample, the metal levels were $\mathrm{Cr}: 0.130 \mathrm{ppm}$ and $\mathrm{Pb}$ : $0.201 \mathrm{ppm}$ which is above the maximum allowable concentration accepted in Bangladesh (Cr: 0.05ppm, $\mathrm{Pb}: 0.05 \mathrm{ppm})$. The selected metals are however very high in the sediments.

Concluding remarks: Dhaleshwari river is polluted and contaminated by toxic metals coming from different industries near the river. The fishes and water of that river are quite unsafe for human consumption. The levels of heavy metals exceed the standard and acceptable level. To mitigate the pollution in Dhaleshwari river, it is recommended to establish a waste water treatment plant in each of the factories and municipal drainage systems near the river and implementation of environmental safety laws strictly.

\section{LITERATURE CITED}

AOAC. 2002. AOAC official method of analysis. Arlington: AOAC International. In: Ashley, K. 1998. Ultrasonic extraction of heavy metals from environmental and industrial hygiene samples for their subsequent determination. Trends in Analytical Chemistry 17: 366-372.

BENDICHO, C. and LAVILLA, I. 2003. Ultrasound-assisted metal extractions. Encyclopedia of Separation Science 3: 4421-4426.

BHATTACHARYA, A.K., MANDAL, S.N. and DAS, S.K. 2007. Bioaccumulation of zinc, copper and lead in upper stretch of Gangetic West Bengal. Trends Applied Sci. Res. 2: 492-499.

BOYLE, J.F., ROSE, N.L., APPELBY, P.G. and BRIKS, H.J.B. 2004. Recent Environmental Change and Human Impact on Svalbard: The Lake-Sediment Geochemical Record. Journal of Paleolimnology 31: 515-530.

FAO. 2010. Trace metals in environments. http://www.fao.org/trace_metals.html.

GoB. 1997. Environmental Conservation Regulation 1997. Government of the People's Republic of Bangladesh. pp. 112-114

HAQUE, W., AHMED, A.T.A., TARAFDAR, S.A., AKHTER, S. and QURAISHI, S.B. 2003. Trace elements in two small fishes (Puntius sophore (Hamilton) and Mystus vittatus (Bloch) of Buriganga river, Balu river and Ichamati beel. Bangladesh J. Zool. 31(2): 247-251

SHARMA, J. and FULEKAR, M.H. 2009. Potential of Citrobacter freundii for bioaccumulation of heavy metal - copper. Biology and Medicine 1(3): 7-14

USEPA. 2000. Drinking Water Quality Standards. United States Environmental Protection Agency. (Available at:] http://www.epa.gov/safewater/contaminents/index.html).

WHO. 1993. Guidelines for Drinking Water Quality. Second Edition, Vol. 2, Health Criteria and Other Supporting Information, WHO. Jeneva. 98 pp. 